\title{
Immaterial labor and civil society organizations: an alternative to refugee ways of working and living
}

\author{
LAURA AlVES SCHERER ${ }^{12}$ \\ CARMEM LIGIA IOCHINS GRISCI ${ }^{2}$ \\ JEAN-FrançOIS ChANLAT ${ }^{3}$ \\ ${ }^{1}$ Universidade Federal do Pampa (UNIPAMPA), SANTANA do LiVRamento - RS, Brazil \\ 2 Universidade Federal do Rio Grande do Sul (UFRGS) / Programa de Pós-Graduação em AdministraçÃo, \\ Escola de AdMINISTRAÇÃO, PoRTO Alegre - RS, BRAZIL \\ 3 Université PARIS-DAuphine, PSL / Dauphine ReCherches en MANAgement (DRM), PARIS - France
}

\begin{abstract}
This article argues that Civil Society Organizations (CSOs) associated with immaterial labor can be favorable alternatives to refugee ways of working and living. We present and analyze the performance of three CSOs - in the areas of theater, handicraft, and gastronomy - aimed at the social and labor integration of refugees, based on the valorization of their savoir-faire and ethnic background. The cartographic method was adopted for qualitative exploratory research. The production and collection of data took place through interaction with managers, refugees, and products and services of the CSOs. Three axes of analysis were considered: (i) presentation of the mapped territory; (ii) CSOs modes of action - learning/teaching, (co)producing/exposing (oneself); (iii) (re)invent (oneself) by (co)operating in a network. The results indicate that, despite new global forms of subjection, CSOs associated with immaterial labor, forge and sustain a network of social, affective, productive, and emancipatory cooperation. This network protects work from the vampirization of the capital and becomes opportunities for refugees in which work and life are intertwined.
\end{abstract}

Keywords: Refugee. Immaterial labor. Civil Society Organization.

\section{Trabalho imateriale organizações da sociedadecivil:alternativa aos modos de trabalhare de viver de refugiados}

\section{Resumo}

Este artigo argumenta que Organizações da Sociedade Civil (OSCS) associadas ao trabalho imaterial podem ser alternativas favoráveis aos modos de trabalhar e de viver de refugiados. Apresentou-se e analisou-se a atuação de três OSCs - voltadas ao teatro, artesanato e gastronomia -, direcionadas à integração social e laboral de refugiados, tendo por base a valorização de seus savoir-faire e background étnico. Adotou-se o método cartográfico para a pesquisa exploratória qualitativa. A produção e colheita de dados remeteram à interação com gestores, refugiados, produtos e serviços das OSCs. Consideraram-se três eixos de análise: (i) apresentação do território cartografado; (ii) modos de atuação de OSCs - aprender/ensinar, (co)produzir/expor(-se); e (iii) (re)inventar(-se) (co)operando em rede. Os resultados indicam que, em que pesem novas formas globais de sujeição, as OSCs associadas ao trabalho imaterial forjam e sustentam uma rede de cooperação social, afetiva, produtiva e emancipatória. Essa rede protege o trabalho da vampirização do capital e desdobra-se em oportunidades para refugiados em que trabalho e vida se entrelaçam.

Palavras-chave: Refugiado. Trabalho imaterial. Organização da sociedade civil.

\section{Trabajo inmaterial y organizaciones de la sociedad civil: una alternativa a las formas de trabajo y de vida de los refugiados}

\section{Resumen}

En este artículo se sostiene que las organizaciones de la sociedad civil (OSC) asociadas con el trabajo inmaterial pueden ser alternativas favorables a las formas de trabajo y de vida de los refugiados. Se presentó y analizó la actuación de tres OSC - en las áreas de teatro, artesanía y gastronomía -, orientadas a la integración social y laboral de los refugiados. El método cartográfico se adoptó para la investigación exploratoria cualitativa. La producción y recopilación de datos se refería a la interacción con gestores, refugiados, productos y servicios de las OSC. Se consideraron tres ejes de análisis: (i) presentación del territorio cartografiado; (ii) modos de actuación de las OSC aprender/enseñar, (co)producir/exponer(se) -; y (iii) (re)inventar(se) (co)operando en red. Los resultados indican que, a pesar de las nuevas formas mundiales de subordinación, las OSC asociadas al trabajo inmaterial forjan y sostienen una red de cooperación social, afectiva, productiva y emancipadora. Esta red protege la mano de obra de la vampirización del capital y se despliega en oportunidades para los refugiados para los cuales el trabajo y la vida están entrelazados.

Palabras clave: Refugiado. Trabajo inmaterial. Organización de la sociedad civil. 


\section{INTRODUCTION}

This article takes as context the modus operandi of contemporary society aligned with the concept of liquid evil, presented by Bauman and Donskis (2019). Liquid evil is characterized by its decentralized, liquefied and pulverized way of operating, that is, the one that "walks in disguise of absence and impossibility of alternatives, [has] surprising ability to flow around the obstacles standing in its way, [makes] all alternative lifestyles seem implausible, even unrealistic, [making resistance to oneself] an even more formidable task" (Bauman \& Donskis, 2019, p. 9).

The mass of individuals who are victims of war, despotism, violence, and brutality, that have been moving in search of refuge and have been increasing excessively in recent years, results from the liquid evil. It illustrates the freedom restricted by the weakening of human relations and the action of the state that pursues it instead of protecting it (Bauman, 2017), being presented as if there was no alternative (Bauman \& Donskis, 2019) but take refuge (Agier, 2016; Bauman, 2017). This mass amounts to 70 million individuals, as reported in 2018 by the United Nations Refugee Agency (United Nations High Commissioner for Refugees [UNHCR], 2018). Considering this, numerous and diverse actors emerge - States, activist movements, churches, local/international organizations, public/private/civil society organizations - leading to the idea of producing means of reception on different fronts (Aparna \& Schapendonk, 2020), including work in intercultural context (Chanlat \& Pierre, 2018).

Studies point out the relevance of Civil Society Organizations (CSOs) regarding social integration and insertion in the labor market of individuals who face forced displacement (Aparna \& Schapendonk, 2020; Comité Economique et Social Européen [CESE], 2017; Kalogeraki, 2019; Meyer \& Simsa, 2018). However, not all work-related initiatives show favorable results. When hiring refugees, sometimes the companies do not take into account their abilities, professional skills or ethnic background (Knappert, Kornau \& Figengül, 2018) and, historically, they are consistent with exclusion, exploitation and precarious employment (Agier, 2016; Bauman, 2017; Knappert et al., 2018). Thus, such practices are configured only as a guise of diversity strategy in organizations (Ortlieb \& Sieben, 2013), but with the capacity to be perceived as something beneficial for refugees, a form that meets the operationalization of liquid evil in society (Bauman \& Donskis, 2019).

In this paper, we argued that CSOs which foster works that mobilize and use combined skills, abilities, potentials and knowledge towards experimentation, creation and production of other knowledge, practices and networks of cooperation may be favorable alternatives for refugees against liquid evil. These characteristics that value the refugees' savoir-faire and ethnic background refer to the concept of immaterial labor (Gorz, 2005; Lazzarato \& Negri, 2001), the one that "needs life as never before, and its product affects life on an unprecedented scale" (Pelbart, 2000, p. 37). The immaterial labor regards both subjection through subtle modes of control and emancipation through the reception of individuals' singular experiences.

Given this, we asked the following question: in a scenario where liquid evil masquerades as the absence of alternatives, how do $\mathrm{CSO}$, in accordance with the notion of immaterial labor and specifically aimed at the social and labor integration of refugees, work? The objective was to present and analyze the performance of these organizations with a cartography to which the path included three CSOs located in Paris/France, that are focused on the areas of theater, handicraft and gastronomy. The production data, which is a result of the act of mapping, stemmed from interaction with managers, refugees, products and services of the CSOs.

Following are the theoretical framework, the method adopted, and the presentation and analysis of the results. Ultimately, the final considerations point out that, despite new global forms of subjection, CSOs associated with the immaterial labor contemplate alternatives to ways of working and living for refugees.

\section{Refuge and Immaterial Labor}

Refugees are the individuals who have fled their country because of a fear of persecution on grounds of race, religion, nationality, social group, political opinion or serious and widespread violation of human rights (UNHCR, 2018). Many of these refugee people were proud of their homes, their education, their jobs and their positions in society, something that turns out to be unknown in the hands of strangers (Bauman, 1999, 2017). 
In the eyes of natives, immigrants and refugees can be seen as "the others" (Bauman, 2017; Berry \& Bell, 2012; Chanlat \& Pierre, 2018), a scornful term to point out that they belong outside the country (Jones, 2008). Such a fact denotes the determinism that what is left to them is a life without alternatives, illustration of liquid evil "impregnated in the fabric of everyday life and [...] embedded in its very core" (Bauman \& Donskis, 2019, p. 9).

In countries that allow visas and work for refugees, their space is usually factories, buildings, restaurants and the service sector, companies that offer long-term, low-wage jobs (Bauman, 2017). Another frequent destination is the informal labor market (Knappert et al., 2018), which can provide better financial return through more working hours and lack of protection. According to Agier (2016), the refugee is currently the one who is always on the border - differing from the figure of the immigrant worker once focused on the logic of material labor. In the host or transit country, the refugee is the one that is in a less stable position and in different precarious anchorages as partial and provisional insertions also consistent with the logic of immaterial labor.

In order to understand the concept of immaterial labor, it is necessary to go back to the idea from which it differentiates, that is, the capitalist production in the fordist period, which was structured by disciplinary and accumulation regimes driven essentially by the general profits of planned and established cooperation within the boundaries of material labor. In the post-Fordist period, on the contrary, there is a tendency towards hegemony of immaterial labor (Lazzarato \& Negri, 2001), in which productive knowledge and social capacities of cooperation diffuse throughout the whole social fabric. Thus, capital exploits the emerging forms of the labor force in a new way, extracting the social wealth produced in common (Negri, 2018).

Current configurations of work and organizations demand a worker who is self- employed, versatile, flexible, mobilized and engaged in the task, a manager of himself in the face of the new production-consumption relationship that characterizes immaterial labor as the one demanding subjectivity (Gorz, 2005; Lazzarato \& Negri, 2001). More specifically, it refers to the "set of bodily, intellectual, creative, affective and communicative activities inherent to the worker, currently valued and demanded as an imposing norm that makes the worker an active subject of work and as an indispensable condition for production" (Grisci, 2011, p. 456). The production cycle of immaterial labor has as an essence the immaterial itself, that is, the subjectivity that activates and organizes the synergy of the production-consumption relationship. This activation occurs through a communicative process, whether through the productive cooperation network (with the most diverse organizations and individuals participating in the production cycle), or through the social relationship (of innovation / production / consumption) between the producer and the consumer who, in turn, also becomes a communicator. The product or service, resulting from different types of savoir-faire and new forms of (self) exposure, generates essentially informative and cultural content and, in this intertwining between producer-consumer, it also generates economic value (Lazzarato \& Negri, 2001).

It is a social and autonomous workforce, in collective forms, networks, flows and cooperation that explains the insertion of workers "into the production process with all the cultural baggage they acquire in games, team sports, in fights, disputes, in musical, theatrical activities, etc." (Gorz, 2005, p. 19). Likewise, the diversity of heterogeneous capacities is valued, "the judgment, intuition, aesthetic sense, level of training and information, the ability to learn and adapt to unforeseen situations" (Gorz, 2005, p. 29).

Immaterial labor takes life in various proportions since "sometimes life is vampirized by the capital - whatever it may be called a market, media or art system - sometimes life is the capital [reinventing its coordinates and changing its forms], that is, a source of value, and the line between one case and another is always thin" (Pelbart, 2003, p. 149). Immaterial labor constitutes, then, a network of productive cooperation through life that, in the CSOs, may evidentiate certain mode of expression.

\section{Civil Society Organizations}

The lack of preparedness of states and leaders to deal with massive migratory flows has led CSOs to play central roles in responding to the needs of individuals in the context of forced displacement (Kalogeraki, 2019). The European Economic and Social Committee (CESE, 2017) recognizes the work of CSOs on different fronts of action, as well as their ability to positively change the landscape of the regions where refugees are concentrated.

UNHCR and CSOs provide free refugee assistance on various topics: access to information and advice on refuge procedures, housing, food, health, education, documentation, language courses, labor market insertion, etc. (Meyer \& Simsa, 2018; UNHCR, 2018). Regarding labor insertion, in general, CSOs' initiatives focus on helping with the preparation of labor documentation, 
teaching the local language and mediating communication between the refugee worker and the private company. However, work positions offered to refugees are less advantageous compared to those offered to natives (CESE, 2017; Knappert et al., 2018; Meyer \& Simsa, 2018).

Knappert et al. (2018) research about Syrian refugees in Turkey - the country with the largest refugee population in the world (UNHCR, 2018) - points out that, to address the urgency for survival, they take up low-skilled job posts (which the natives do not want) in areas that they have no experience. Thus, because they work long hours, they do not have time to take advantage of the training offered by CSOs. Furthermore, due to the large volume of refugees, CSOs are not able to reach all of them when they arrive in the host country, which results in many of them going to informal jobs (Knappert et al., 2018).

Ortlieb and Sieben (2013), in their study of ethnic minorities in organizations, argue that valuing the ethnic background and skills of these workers, including refugees, is the key factor for these individuals to escape precariousness and exploitation and for organizations to model good practices of diversity management. Although this research has been developed based on private organizations, in line with the CESE (2017), Chanlat and Pierre (2018) and Knappert et al. (2018) indicators, we argued that CSOs should seek to increase their efforts to ensure fair and equitable treatment towards enhancing the skills of refugees.

Aparna and Schapendonk (2020) value these characteristics in a study on the "Asylum University", a project carried out in a refugee camp with the objective of developing art activities, language classes and sharing experiences. The interaction between researchers, students, refugees/immigrants and local residents has enabled them to actively flow through the changes in social relations between native hosts and foreign newcomers, creating intermediate spaces, (im)mobility, border crossings, emotions entwined in a tangled web of hospitality. Such implementation coproduced actions, communication and relationships with the actors which favored the expansion to other refugee camps.

The results of Aparna and Schapendonk's (2020) research denoted a possible approximation of the operational characteristics of immaterial labor production cycle, and opened the way for further research on CSOs that focus on refugees.

\section{Cartographic Method}

Cartography "is a drawing that accompanies and is done at the same time as landscape transformation movements" (Rolnik, 2006, p. 23). Thus, it proposes the registration of transformations in the territory and the follow-up of routes. It should be noted that this is not a geographical territory, but an existential one, with subjects and landscapes in a constant production process (Alvarez \& Passos, 2015). The cartographic method uses clues as "references that contribute to the maintenance of an attitude of openness to what is being produced and of calibration of the walking in the research path" (Passos, Kastrup \& Escóssia, 2015, p. 13). There were clues to the cartography, among them: not separating research and intervention; monitoring processes and movements-functions of devices in practice; paying attention to collectives of forces as a cartographic experience plan; inhabiting an existential territory and promoting changes in narrative practices.

Starting from the initial theoretical association - refuge and immaterial labor - we began a cartographic journey conducted in Paris/France, which led us to three CSOs. The first was accessed through the researchers' contact network, the others through Facebook. They were named according to their area of expertise: Théâtre, Artisanat and Gastronomie. The aim was to "map a territory that was not inhabited in principle. It is not a matter of moving in a known city, but of producing knowledge through a research path, which involves attention and, with it, the very creation of the observation territory" (Kastrup, 2015, p. 45). It is important to say that a fourth CSO also participated in the initial phase of cartography. However, the managers did not allow interviews to be carried out, nor the monitoring of activities performed by refugees for academic purposes. Therefore, this CSO was not included in this study, but this exemplifies part of the difficulties in accessing this research territory.

The three participant CSOs have been visited numerous times, between november 2018 and april 2019, so that we could learn about the place, the members involved and the service they provide. The confirmation of the valorization of the savoir-faire and the ethnic background of refugees as CSOs mode of action proved to be consistent with the notion of immaterial labor and continued the cartographic course, as follows. 
We found Théâtre through the assistance of a play presented in a cultural space whose agenda of the week contemplated the theme of refuge. A conversation about the cartography with producers, actors and support team of the play allowed the inclusion of one of the researchers in a season of ten theater studio sessions, for a period of two and a half months. Sunday sessions of approximately five hours each took place in a room that was lent by a non-governmental organization (NGO), and resulted in free theater production presented on a Parisian university stage, in which one of the researchers also acted.

We came to know Artisanat during a lecture given by its director at an event about refuge and art at a university. The first visit enabled us to see the space for workshops and exhibition of products for sale-accessories and clothing, ceramics and tapestry-, as well as conduct informal conversations with employees, artisans and customers. In total, four visits of approximately one hour each occurred. The invitation of a French employee of the organization resulted in the participation of one of the researchers in a jewelry workshop conducted by a refugee.

Gastronomie was found directly in the pasta workshop of a female refugee who, with the manager of the ateliers and some French volunteers, commanded a class of 15 students in a cultural space with an independent food court. In this space, there is also a restaurant that operates daily by a Colombian chef who, every six months, receives a refugee chef to prepare typical meals of their country. Five visits of approximately one hour each occurred, and there were tasting of dishes from different countries.

Throughout the cartography, we paid attention to the dynamics of CSOs' performance, as well as to informal conversations and to printed and virtual documentary sources - institutional leaflets, product catalogs, menu of typical dishes that exposed the refugees' situation in the form of disclosure and monetization. Facebook and Instagram served to follow publications in partnership with museums, universities and media, and the very unfolding of refugee life. After each visit and workshop, there were records in the cartographic logbook. They give back an expanded analytical text because they print ideas from both researchers and participants.

The approach with the interviewed managers and refugees took place gradually considering one of the researchers' constant presence and interaction through social networks on the internet and emails. Only after the bonds of trust were established, the interviews were carried out at each person's preferred location. Interviews with five managers took place within the organizations themselves and lasted an average of 45 minutes. There was the participation of Théâtre's managers of Projects, Communication and Artistic Creation, the manager of Artisanat's Workshops and the manager of Gastronomie's Events. Interviews with five refugees - in French and/or English - took place in cafes, parks or houses, and lasted an average of two hours. A female refugee did not allow the recording of the interview, something associated with the situation of the refuge. Refugees from Théâtre - teacher-actor from Turkey and students-actors from Afghanistan and South Sudan; Artisanat jeweler- artisan from Togo; and Gastronomie - chef from Georgia were interviewed.

Cartography required a constant return to the theory, listening to participants' speeches, the logbook, and the handling of distribution materials in order to intertwine analytical differences. The analyses took place at all times of the study and not only after data production and collection (L. Barros \& M. Barros, 2013). In a procedural manner, we relied on the theory and looked out for shared experiences not always obvious or instantly accessible. It resulted in three axes: (i) presentation of the mapped territory; (ii) CSOs modes of action; and (iii) (re)inventing oneself by (co)operating on a network.

\section{Presentation of the Mapped Territory}

In addition to differentiating themselves from other refugee-related CSOs regarding housing, food and documentation, the organizations in this study focused on social and labor insertion with an emphasis on valuing the savoir-faire and ethnic background of these individuals. Given the sensitivity to the refugees vulnerable situation and to the understanding of the transformative capacity of art, CSOs operate in the areas of theater, handicraft and gastronomy. They have similarities and differences.

Théâtre promotes spaces of integration and sharing to connect people, stories and cultures. The relevance given to this is found in the speech, which is sensitive to refugee vulnerability regarding liquid evil: "We really design a space to share with these people, where they express themselves in their own way. Talking, singing, having emotions, expressing them through the theater, because it's like a place where everything is very safe. We take care of each other. You can be from anywhere in the world" (MANAGER/COMMUNICATION). 
Théâtre is run by three female immigrants - from Colombia, Mexico and Russia - who met each other when they were attending a Master's degree course in Cultural Policy. They are, respectively, managers of production, art and projects. Production and art managers volunteered for a former itinerant refugee theater project that started in 2015. In 2019, by prioritizing the maintenance of the same participants, this project became Théâtre as a cultural activity for the university.

In addition to the managers and the Drama teacher, a Turkish refugee, volunteers help with management tips and theatrical production. The cast of refugees changes weekly. "Six people started, then 10, 20" (MANAGER/PROJECTS). Beginners commit to staying until the final presentation. There were "Afghans, Syrians, Egyptians, especially Sudaneses. Turkey, Pakistan, Kuwait. Most are in the process of obtaining refugee status. In order to act, you don't have to come with a visa or have this status" (MANAGER/ARTISTIC CREATION).

Théâtre has a Facebook page to show the work offered and invite refugees and volunteers to participate. There are no restrictions or prerequisites for continuous flow admission. There is also a private page where volunteers and refugees visit to post and share ideas, feelings, photos and videos. Weekly rehearsals over the course of three months culminate in a free, open theatrical performance on the expected "show day". The audience participates by posing questions, reading poems and speaking. Each member of the presentation acts considering sketches produced by the collective, giving an idea of political theater. Thus, situations of refuge are staged and (re)lived in a safe condition, with a tragic- comic tonic that seeks public awareness about them. The permanence of refugees and volunteers in the organization varies according to the dynamics of their lives.

Artisanat is a social entrepreneurship organization founded on the values of innovation and solidarity. It values and promotes the professional integration of artisans-refugees and artisans-immigrants. Like Théâtre, Artisanat seeks to counteract liquid evil. Its goal is to "integrate and enhance the savoir-faire of refugee artisans, to put them in a more important and a little more dignified position. Many times they have completely lost their dignity, they no longer have self-confidence" (MANAGER/ATELIER).

Artisanat emerged in 2016 from the identification of its founder with the cause of refugees because her mother, an embroiderer in her home country, had not seen possibilities for maintaining her craftwork in France. The team consists of a founding director, staff and volunteers. They work with customer service, purchasing, inventory, sale of products and management of workshops for craft practices such as jewelry, tapestry, among others. One of the employees is a professional insertion counselor who helps them with resumes and seeking for internship and job offers. Artisanat also counts on professional references in different areas of crafts and designers who help artisans-refugees.

In order to participate in the organization, one needs to go through a selection process that values prior experience with handicrafts in their home country and regular refugee status. This is necessary for the formal work bond performed as one of Artisanat's goals. Six artisans-refugees were there at the moment of the cartography, and more than 20 had been welcomed by Artisanat between 2016 and 2018. In training for six months, they work on two fronts - their own production and workshops for the general public. They are paid by both, although the focus is on the training and dissemination of work which is broadcast on television, electronic and print media and surprises by the quality of content and art of the material used. Custom and limited series collections are a showcase of savoir-faire in close proximity to immaterial labor. The objects produced symbolize the passage between Artisanat and the professional world, and announce the opening of a new path that involves refugee life history and a future as an artisan in France.

Gastronomie seeks, through the kitchen,

(1) value talent, cultural and culinary heritage by showing that refugees have very rich talent, history, culture and heritage. The idea is to change the way we look at refugee status, to get out of miserable speeches by talking about something very positive; (2) work on the professional integration of refugees through the kitchen; (3) bring citizens closer, create a commitment around the table that is a place of peace and equality, a completely universal place (MANAGER/EVENTS).

Gastronomie was founded in 2016 by a French couple who, traveling around the world, realized that in any country it is possible to get closer to others and communicate through food even without knowing the local language. Such a perception became a philosophy shared by the organization's employees. "Cooking with people, tasting and changing to make food is like a gateway to each other, and allows you to share countless things. It's really something universal and it's also very personal, it's very intimate" (MANAGER/EVENTS). 
The organization provides four working fronts for refugee chefs - a home-country restaurant and kitchen workshops located in a food court, catering services and annual festival where the refugee chef acts as a renowned restaurant chef. In addition to the managerial couple, in the restaurant kitchen there are three employees and the responsible Colombian chef, who has made a career in France. French volunteers and from other nationalities who seek for integration also participate.

To participate, it is not important if the refugees have not been chefs in their country, they just need to cook and want to work in the area. As with Artisanat, refugee status is required. More than 150 refugee chefs have participated in some of Gastronomie's activities. The Festival, which started in 2017 only in the city of Paris, grows every year and in 2019 it happened in 15 cities in Europe, the United States and South Africa. Among the diverse citizens, local authorities, organizations and partner restaurants, UNHCR is co-organizer of the Festival. As in Artisanat, the activities developed by Gastronomie attract the attention of all types of media, which helps to "evolve the attention to refugee status", according to a leaflet for publicity.

These CSOs are presented in the logic of immaterial labor, having in the mobilization and profitability of themselves the assumption and primacy of the cooperation network as a mode of operation.

\section{CSOs modes of action}

CSOs modes of action are presented in verbal compositions: learning/teaching and (co)producing/exposing (oneself). These compositions embody the characteristics of productive cooperation and social relations that, through a communicative process, make up the production cycle of immaterial labor according to Lazzarato and Negri (2001).

\section{Learning/teaching}

Théâtre impresses as "a predominantly male, young place where you can hear French, English, Arabic, Spanish and African dialects. In this environment, people take Drama classes, some of them somewhat acquainted with the craft of acting, others more timid who are slowly letting go" (LOGBOOK). The main activity developed refers to theater art studios. On a routine basis, during cold Sunday afternoons, after the welcome in French and English, "for four, five hours, we would act in little plays, skits, play games, make vocal and body exercises. In the theatrical rehearsals, we discussed several subjects, danced. We really wanted them to build the show with their own ideas" (MANAGER/COMMUNICATION). The Refugee/Turkey took over as a Drama teacher.

Theatrical exercises required imaginative ability to mimic, create, and improvise stories; communicative ability to mimic sounds, gestures, and revealing looks of a character's characteristics. The body disposition to sit, stand, jump, crawl could be seen by someone unaware as a huge mess. The personal experiences of the refugees necessarily were imprinted in their actions in the improvisation of sketches and evidenced: (1) characteristics of the countries of origin - greeting, dancing, veiling in women's roles, refusing to play certain roles; (2) experiences in France - use of politeness understood as typically French to be well served in a cafe; baguette placed under the arm, dispute for space on a crowded subway; (3) refugee situations trips to police offices, requesting documents, facing a barrier and police violence for being a foreigner. Thus came into play the teacher-actor-refugee that was instrumental in transforming those tense moments. By representing personal experiences, theatrical scenes point to a time that does not distinguish past-present-future, making it possible for art to review, organize, elaborate and produce other ways of working and living (Lazzarato \& Negri, 2001).

Although not all theater participants speak French or English, "we saw that what was working well [...] is the plasticity of the theater, which allows us to communicate not only through words. So sometimes it is not necessary to translate. It is necessary to give instructions, but for the scenes, if the scene is good, it is beautiful, it works in Arabic, we do it in Arabic" (MANAGER/PROJECTS). This can be seen in the "skit in which Refugee/South Sudan buys a train ticket, something that may go unnoticed in the daily actions of natives" (LOGBOOK). Although through verbal communication in the mother tongue, the theater allowed the actor to learn/teach and the public to understand the extent of difficulties faced by refugees. Something that had not occurred in unstaged life, but that occurred on stage by the work of mobilizing oneself $(\mathrm{Gorz}, 2005)$ that theater requires and provides. 
In Artisanat, cozy exhibit and sale spaces coexist, artisan's work bureau and craft classrooms. When arriving at the organization, the refugee experiences qualification through partnerships. "In fact, all of us and everything we do is part of the training. Artisan refugees start with other French artisans: reference-artisans. Then come product designers, web designers, architects, and fashion designers to work together. Therefore, teaching is always an exchange" (MANAGER/ATELIERS).

It is common to look for jewelry models from the country of origin on the internet, to show the details to the reference artisan and the designer, "in my country I worked with gold and silver. I learned this way, I liked it better. Here at Artisanat I work more with brass and copper. It's harder to handle, but you can still make beautiful pieces" (REFUGEE/TOGO). In the process of learning/teaching, the training of Artisanat rescues the cultural baggage acquired throughout life and puts it into action to work (Gorz, 2005).

The training also refers to social, cultural and labor market standards in France, and is an occasion to practice French language. In line with Negri (2018) on social cooperation as immaterial labor, it is emphasized: "We will teach you how things work in the French market, what to do to integrate into the French economy, how to speak French well. The artisans allow them to practice the language, have a professional posture and thus teach and pass something on. This is what we are trying to get done: little things that we need to know how to do in order to evolve in the profession" (MANAGER/ATELIERS).

In Gastronomie, learning/teaching takes place at the organization's restaurant and at the Festival's partner restaurants between the refugee-chef and the reference-chef. The idea is to encourage the refugee-chef to show his ethnic background, the best of his own culinary. "He/she must have cooking ideas, be the actual leader. The reference-chef only shows how it works because he knows the menus that will or will not please customers. Sometimes we try something different and then change, redirect" (MANAGER/EVENTS).

This also offers services that arise in response to refugee demands. "Many chefs want to set up their own business, so we have implemented the catering service, offering chefs the possibility to test themselves at our own events by creating a catering menu. Let them learn at French events and then launch themselves" (MANAGER/EVENTS). Preparation for self- management exercise (Gorz, 2005).

The refugee-chef must cook from his or her experiences refurbished in the tastes and culture of the destination country taught by the reference-chef. Activity that requires mobilization of subjectivities capable of forging new combinations for the work. The very domestic experience and traditions of the country of origin stand out in the preparation of a rich table. Something experienced for life is good for the work, and keep learning/teaching with the reference-chef. "I cook in the restaurant like I do at home. I think every Georgian woman can be a chef, because she's used to having events for 20, 300 people, at weddings, birthdays[...] You can't come to my house and have just a glass of wine and some appetizers. The table will have to be with 1000 types of food. I'm so happy, it's my culture" (REFUGEE/GEORGIA).

The reference chef teaches cultural codes of French gastronomy. His or her job is to accompany and train chefs, to check their hygiene and safety training needs or whatever they need to know. "In France, there are many standards to be adopted in the kitchen. There is a lot of hygiene and safety control, it is necessary to have shoes and a hair cap, respect the hot and cold cycles. There are tough rules even for those who took a course. You have to say bonjour, explain the menu, communicate with the French clientele. There are many cultural differences, we show them what it is like to cook in France" (MANAGER/EVENTS).

Learning/teaching is mobilization and self-investment that, in the logic of immaterial labor, is energized in time-space and the cooperation networks that are forged in it.

\section{(Co)producing/exposing (oneself)}

Théâtre's flagship product, the show held at a Parisian university was co-produced mainly during the workshops by teacherstudent-actor-refugees and volunteers. "We took the best ideas that emerged from the exercises and created a show with them" (MANAGER/COMMUNICATION). The participation of French volunteers is highlighted in order to make known the ways of being and living of Parisians and to change the way natives look to the refugee as "the other" (Bauman, 2017). In line with the study by Aparna and Schapendonk (2020), it is not a one-way, paternalistic relationship of the organization with refugees, 
but a co-participatory relationship. Skits, scenographic objects with recycled material and the promotion of the play were co-produced at Théâtre. This is a "by, for and with refugees" organization (MANAGER/PROJECTS).

The network for supporting the project included: digital crowdfunding platform with sufficient return for the purchase of stage materials and snacks for the workshops; NGO with loan for testing venue; an English actor-producer who helps by consulting on performing arts; university with subway tickets for attendees, print promotional materials and show stage. Lacking experience, managers say "how naive we were." Co-production was possible due to technological, communicational, relational and organizational devices (Gorz, 2005; Lazzarato \& Negri, 2001; Negri, 2018).

Exhibiting the final product of Théâtre means making the show viable by exposing the refugees to the public. The title of the show printed on promotional materials refers to the phoenix, a mythological bird that is reborn from its own ashes. The phoenix is associated with the (re)invention of refugee life in the face of harsh evidence of liquid evil. The title also refers to a "spectacle created by refugees", which somehow makes the refugee figure profitable by exposing their existence and their pains.

Beyond the stage, to be a refugee is to be on constant display. The idea of making a traveling show through the streets of Paris was denied by the city, because on the day of the show there were manifestations of the movement of the yellow vests.

Everyone gathered in the morning at the NGO where the workshops took place, did one last rehearsal and shared lunch. From there they went together by subway to the university, carrying bags with costumes and scenic objects. They were happy, excited, talked loudly, and sang. The refugee-teacher-actor and the managers were in charge of keeping the group together in order to mitigate a characteristic refugee concern thus verbalized: "So-and-so, it is full of police on the streets, now there are yellow vests. Do you want to go to jail? We don't have the definitive documents yet", says the refugee-teacher-actor (LOGBOOK).

In the script of the show, stories inspired by real refuge and refugee everyday situations swayed in shades of tragedy and comedy - broken and unreachable dreams, bombing deaths, censored expressions, border barriers, bureaucratic difficulties in applying for asylum, power of meeting cultures and languages. Ways of refuge reflected in the characters on the scene allowed for art consumption. For the theater it did not matter where the refugees came from, but rather the situation of refuge taken as an enactable sensitizing device for the public, illustrating a life-art-work-product-consumption relationship (Pelbart, 2003). Thus, (co)producer/(co)production/product/exhibition/consumption are found amalgamated in the affective cooperation network that still seeks to "make friends, start a small family, create a new life here" (MANAGER/COMMUNICATION).

At Artisanat, the handicrafts produced are the result of a (co)production started since the period the artisan-refugee is being trained in partnership with the reference-artisans and designers. "I explain what materials I need to make the costume jewelry and the organization provides. The designer looks at Togo's designs, the types of jewelry on the internet to see what it's like in my country. And we will create the pieces together" (REFUGEE/TOGO). When safe, refugees-artisans give workshops in conjunction with Artisanat staff. "During the costume jewelry workshop, the reference-artisan assisted around ten students by handling the tools and translating French words and expressions to the artisan-refugee. Each student produced a ring and bracelet for her own use. The studio manager welcomed students and made photographic records" (LOGBOOK). Excited, the artisan-refugee commented on the preparation of the workshops in the organization and other social spaces in Paris. "I have participated in workshops here at the organization's headquarters and in museums as well. It was for the people who were going to visit the museum".

Refugees provide visibility and profitability for the CSO which, in brochures and electronic, print and television media, make the following calls: "Join a hands-on practical workshop with an artisan refugee"; "Have a unique and caring experience, a cultural trip"; "Let's change the look and value your knowledge". The media's gaze returns to CSOs with headlines: "Refugees return to their craft skills"; "Fashion network: workshops to help refugees get in"; "Organizations propose another look at refugees". This way the network of social and productive cooperation becomes visible because "the artisans, as well as the general public, make the most of the moments. And we benefit, it is comforting to know that our organization is helping society value the refugee's knowledge. The artisans themselves help each other a lot, they have all made huge progress in French" (MANAGER/ATELIERS).

The exhibition of handicrafts in person and online, and in partnerships, promotes the savoir-faire of refugees and establishes initial contacts with companies that have potential for hiring. The collection portfolio has one page for each object. It details 
the materials and history of each piece, as well as the collaborating designers. Besides, it highlights photography of the artisan refugee, his or her home country and experience in the profession. Each piece is named in the mother tongue of the refugee artisan in order to identify ethnic and cultural aspects and add value. These aspects constitute the signature of the artisan refugee who (co)produces limited edition pieces with values between 60 and 150 euros as disclosed in the collection folder. The amounts collected are distributed as follows: $30 \%$ artisan, $15 \%$ raw material, $20 \%$ experimental phase and $35 \%$ CSO. Artisanat discloses the existence of a collaborative ecosystem dedicated to handicrafts. It is a work of cooperation that "emancipates, which produces an increase of being" (Lazzarato \& Negri, 2001, p. 89), and is organized in such a way as to contribute to the dynamics of the social economic fabric.

At Gastronomie, the main product is the typical dish of the refugee chef's country, (co)produced with reference-chefs. The idea is the collaborative "four-handed menu" (MANAGER/EVENTS) in all formats. "Sometimes it's carte blanche to the guest refugee cook. That's it, the idea is to revalue the culinary heritage to regain self-confidence through a network that makes it possible to set foot in the stirrup in order to insert oneself in the kitchen of France" (MANAGER/EVENTS).

They collaborate on (co)production, combining chefs' favorite ideas and ingredients. In the restaurant, there was a tension between the original and the French food. "I'm making a new kind of proposal, my food [...] But we are living in France. So, I respect people and adapt my menu. I am not making traditional Georgian food [...]. The chef said to me: Don't do it because now you're not doing it for Georgians, but for French, do it like this, like this" (REFUGEE/GEORGIA). Such tension dissipated in a workshop where the use of cell phones took over the kitchen-classroom. Each ingredient shown was highlighted. Each step taken in the recipe resulted in a video. The Refugee/Georgia herself recorded the preparation of the dish and the interaction with the students in live streamings. Exposing (oneself) is continually working (Gorz, 2005), which gives her commendable comments on her social network and legitimizes the cooperation network. One of the comments that made tears come to her eyes was that of a compatriot "You are an ambassador for our culture congratulations and thank you!".

Gastronomie promotes a traveling gastronomic festival that alludes to World Refugee Day and provides exposure of the refugee's situation to other continents. The festival follows a methodological kit with best organizational practices regardless of where it is held, and is co-organized by UNHCR, among others.

Individually or collectively, (co)producing/exposing (oneself), as well as learning/teaching, promotes a network of cooperation around the refugee situation, and provides (re)invention of oneself as an alternative to liquid evil.

\section{(Re)invent (Oneself) by (Co)operating on a Network}

Théatre constitutes an extension of the refugee route. "I'm enjoying the theater, I act with the heart, I act my reality. People applaud and say, 'You're a great actor!'” (REFUGEE/AFGHANISTAN). "When my friends [refugees] told me about drama classes, I saw a chance. I went to the theater because I want to be an artist who can sing, perform" (REFUGEE/SOUTH SUDAN). The theater concomitantly shows a way of working and living. The following statement are even more striking in this regard:

When you're under stress, something that you can't seem to find a solution to, you have to find something else to put in space, you know? Before Théatre I was dead, as if I couldn't feel my soul in my body, really empty, it was as if I had no emotion in my body, I was just living to eat, just surviving. I was like a dead man. After the theater I started smiling! Of course I need money that is so important, but what I need more than money is something mentally, you know, smile, hug, share my problems, talk about something, know what I'm saying, that's why they are so important to me, it's not just a theater (REFUGEE/TURKEY).

It is observed the production of difference related to ways of working in the praise received for the performance, and the desire to become an artist; and ways of living in the repeated sense of "death" that changes through acting and living together. The theater as the test/staging/repetition is, for refugees, like a chance of facing the liquid evil as "deterministic society, pessimistic and fatalistic" (Bauman \& Donskis, 2019, p. 16).

(Co)produce/exhibit (oneself) unfolded in invitations and opportunities for Théâtre refugees in the form of short-term fashion design courses at renowned university, documentary acting, and residency at Cité International des Arts de Paris. Something 
relevant for those who had another profession in their home country and now consider "include actor, continue acting" (REFUGEE/AFGHANISTAN).

The experience of artisan-refugee in Artisanat was an opportunity to return the work to a subtracted level, which is associated with the resumption of intertwined work/life (Pelbart, 2003) or the (re)invention of ways of living. "Jewelry is my life! Artisanat has given me the opportunity to resume my life!" (REFUGEE/TOGO). While still in training, the refugee showed interest and saw in particular the possibility of being hired by a jewelry company at the expense of opportunities to work as a nanny and maid, usually presented to women refugees.

Teaching/learning and (co)producing/exposing (oneself) unfolded in stages in companies seen as a gateway to the labor market. "With seamstresses and embroiderers, this is very common. They are hired by the fashion industry" (MANAGER/ATELIERS). The time at Artisanat also encouraged other refugees to open small businesses, as exemplified by the opening of a ceramics company, as well as the continuity of their work as artisans in other associations that help refugees.

Continuing to work and learn from a famous chef in haute cuisine to qualify their own venture exemplifies that the cooperation network goes beyond the time spent at Gastronomie. Among its developments are the launching of enterprising chefs in autonomous working styles considered to be appropriate to the refugee host society: the opening of a bistro with its own refugee name often exposed on social networks and traditional media; provision of catering services; and annual participation in Festival that has already won awards for best gastronomic event in fierce competition.

In the experience of unimaginable situations in the face of refuge, the feeling of having the work awarded is presented in superlatives. "It was like the Oscar nominations. We got there, were nominated, and took the stage. It was absolutely the same as Oscar" (REFUGEE/GEORGIA).

Developments in the modes of action of the three CSOs indicated repetition as difference, reaffirmation of savoir-faire and ethnic background, production of unusual things and obtaining unimagined recognition in order to stimulate (re)invention of oneself in the logic of immaterial labor as an alternative to refugees. Cooperation networks are forged and sustained in CSOs performance in a social, affective, productive and emancipatory perspective. Network members recognize the refugee situation as a humanitarian cause; create bonds of friendship; recognize the refugee as a source of value and profitability for CSOs themselves, universities, museums, restaurants, media, reference professionals, volunteers; it is possible to see that they constitute autonomous trajectories.

Figure 1

CSOs cooperation network: members, modes of action, developments and perspectives

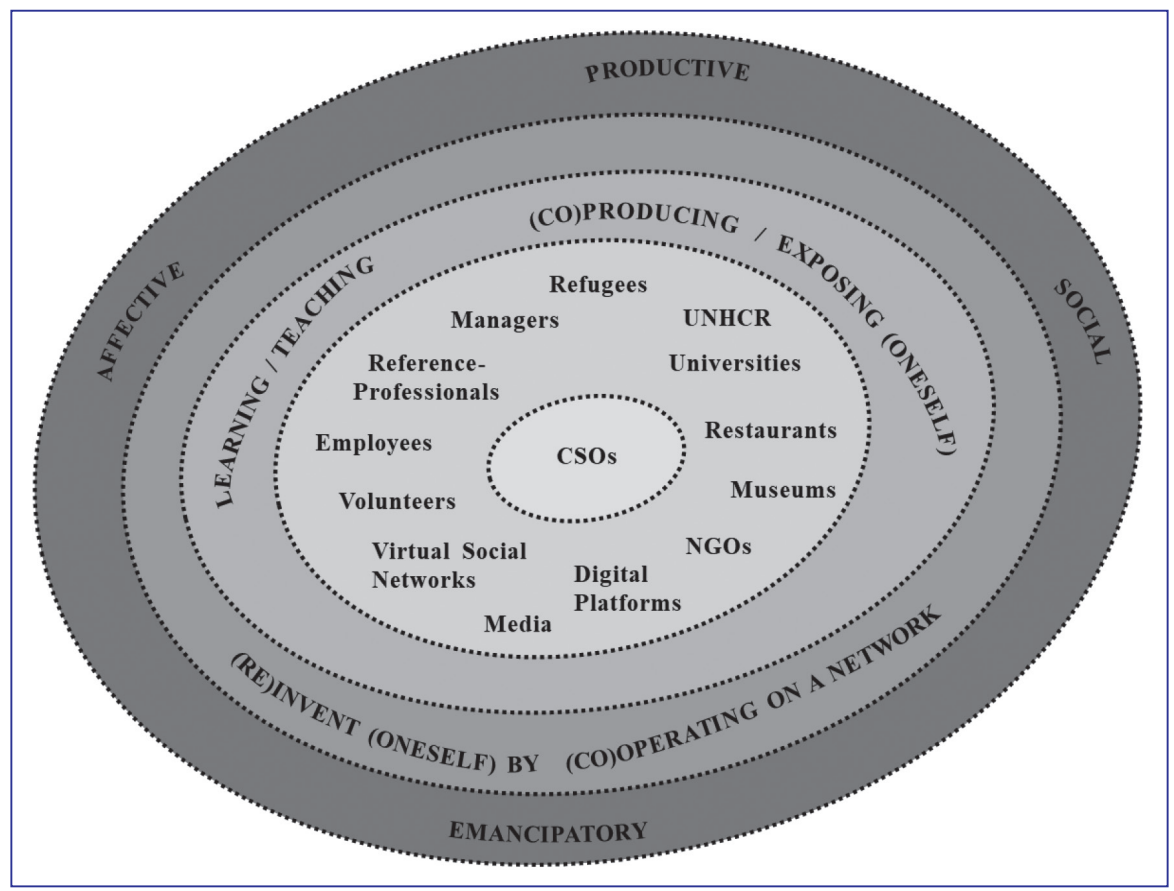

Source: Elaborated by the authors. 
Immaterial labor is constituted under collective forms, flows and networks of cooperation that concern life. "Really, it is never an individual, or even a group of individuals (inter-subjectivity), who works, communicates or produces. [...] As well as "it is never the individual who thinks or creates" (Lazzarato, 2017, pp. 43-44). The individual works or produces within and through collective agency, within a network of institutions, technologies, sources of funding, immersed in traditions of aesthetic thoughts and practices. Thus, cooperation networks are progressively reinforced until their exploitation as a social activity (Negri, 2018). Although "capital exploits life, it does not mean that life coincides with capital" (Lazzarato, 2017, p. 237).

Cooperation networks are indispensable to immaterial labor. In mapped CSOs, the cooperation network contemplates learning/ teaching and (co)producing/exposing (oneself), supporting (co)operation and (re)invention of oneself in order to overcome constraints of origin, time-space and knowledge to affirm life.

\section{FINAL CONSIDERATIONS}

Based on the association between refuge, immaterial labor and CSOs, the objective was to present and analyse the performance of CSOs directed towards the social and labor integration of refugees, in order to enhance their savoir-faire and ethnic background. The cartography that took three CSOs - which are related to theater, handicraft and gastronomy - proved to be a possibility of comprehensive and adequate approximation to the flows and forces that are established as a result of forced displacements.

CSOs modes of action include learning/teaching and (co)producing/exposing (oneself), sustaining (re)invention by (co)operating on a network. Such actions are actively and collaboratively articulated in order to forge and sustain the social, affective, productive and emancipatory network of cooperation in an intercultural context (Chanlat \& Pierre, 2018). It is noted that the performance of individuals in a cooperation network embodied in immaterial labor becomes an organizational movement and, in turn, becomes an interorganizational movement. This network protects the work from the vampirization of the capital, through refugee organizations, and results in opportunities for refugees in which work and life intertwine.

The main contributions of the study include: (i) the cartographic method that contributes to the approach and participation in dynamic, intensity and difficulty to reach territory; (ii) the visibility of the cooperation network-social, affective, productive and emancipatory - in order to highlight the immaterial labor in CSOs; (iii) in a scenario where liquid evil masquerades as the absence of alternatives, despite new global forms of subjection, CSOs associated with immaterial labor include alternatives to refugee ways of working and living.

The language proved to be an important limitation. A longitudinal study is suggested in order to follow the developments of the CSOs cooperation network and the way refugees work and live.

\section{ACKNOWLEDGEMENTS}

To CAPES/PDSE - Process n. 88881.190579/2018-01. 


\section{REFERENCES}

Agier, M. (2016). Les migrants et nous: comprendre Babel. Paris, France: CNRS Editions.

Alvarez, J., \& Passos, E. (2015). Cartografar é habitar um território existencial. In E. Passos, V. Kastrup, \& L. Escóssia (Orgs.), Pistas do método da cartografia: pesquisa- intervenção e produção de subjetividade (pp. 131-149). Porto Alegre, RS: Sulina.

Aparna, K., \& Schapendonk, J. (2020, November). Shifting itineraries of asylum hospitality: towards a process geographical approach of guest-host relations. Geoforum, 116, 226-234.

Barros, L. M. R., \& Barros, M. E. B. (2013). O problema da análise em pesquisa cartográfica. Fractal: Revista de Psicologia, 25(2), 373-390.

Bauman, Z. (1999). Globalização: as consequências humanas. Rio de Janeiro, RJ: Zahar.

Bauman, Z. (2017). Estranhos à nossa porta. Rio de Janeiro, RJ: Zahar.

Bauman, Z., \& Donskis, L. (2019). Mal Líquido: Vivendo num mundo sem alternativas. Rio de Janeiro, RJ: Zahar.

Berry, D., \& Bell, M. (2012, January). Expatriates": Gender, Race and Class distinctions in International Management. Gender, Work and Organization, 19(1), 10-28.

Chanlat, J. F., \& Pierre, P. (2018). Le management interculturel. Evolution, tendances et critiques. Caen, France: Editions Management et Société.

Comité Economique et Social Européen. (2017). Comment les organisations de la societé civile viennent em aide aux réfugiés et aux migrants dans I'Union Européenne: experiences réussies et pratiques prometteuses tirées de l"édition 2016 du prix de la societé civile du CESE. Maastricht, The Netherlands: Union européenne.

Gorz, A. (2005). O imaterial: conhecimento, valor e capital. São Paulo, SP: Annablume.

Grisci, C. L. I. (2011). Trabalho Imaterial. In A. D. Cattani, \& L. Holzmann (Eds.), Dicionário de Trabalho e Tecnologia. Porto Alegre, RS: Zouk.

Jones, A. (2008). A silent but might river: the costs of women"s economic migration. Signs: Journal of Women in Culture and Society, 33(4), 761-769.
Kalogeraki, S. (2019, June). A Mixed Method Approach on Greek Civil Society Organizations Supporting Migrants During the Refugee Crisis. Journal of International Migration and Integration, 21(1), 1-26.

Kastrup, V. (2015). O funcionamento da atenção no trabalho do cartógrafo. In E. Passos, V. Kastrup, \& L. Escóssia (Orgs.), Pistas do método da cartografia: pesquisa-intervenção e produção de subjetividade. Porto Alegre, RS: Sulina.

Knappert, L., Kornau, A., \& Figengul, M. (2018, April). Refugees' exclusion at work and the intersection with gender: Insights from the Turkish-Syrian border. Journal of Vocational Behavior, 105(esp.), 62-82.

Lazzarato, M. (2017). O governo do homem endividado. São Paulo, SP: $n-1$ edições.

Lazzarato, M., \& Negri, A. (2001). Trabalho imaterial: formas de vida e subjetividade. Rio de Janeiro, RJ: DP\&A.

Meyer, M., \& Simsa, R. (2018, December). Organizing the Unexpected: How Civil Society Organizations Dealt with the Refugee Crisis. Voluntas, 29(6), 1159-1175.

Negri, A. (2018). Travail Vivant contre Capital. Paris, France: Les Éditions Sociales.

Ortlieb, R., \& Sieben, B. (2013). Diversity strategies and business logic: Why do companies employ ethnic minorities? Group \& Organization Management, 38(4), 480-511.

Passos, E., Kastrup, V., \& Escóssia, L. (2015). Pistas do método da cartografia: pesquisa-intervenção e produção de subjetividade. Porto Alegre, RS: Sulina.

Pelbart, P. P. (2000). A vertigem por um fio: políticas da subjetividade contemporânea. São Paulo, SP: Iluminuras/FAPESP.

Pelbart, P. P. (2003). Vida Capital: ensaios de biopolítica. São Paulo, SP: lluminuras.

Rolnik, S. (2006). Cartografia sentimental: transformações contemporâneas do desejo. Porto Alegre, RS: Editora UFRGS.

United Nations High Commissioner for Refugees. (2018). Global Trends - Forced Displacement in 2018. Geneva, Switzerland: The United Nations Refugee Agency. 
Laura Alves Scherer

ORCID: https://orcid.org/0000-0003-1803-3014

Ph.D. in Business Administration from Federal University of Rio Grande do Sul (UFRGS); Assistant Professor at Federal University of Pampa (UNIPAMPA).

E-mail: laurascherer@unipampa.edu.br

Carmem Lígia lochins Grisci

ORCID: https://orcid.org/0000-0002-7034-4007

Ph.D. in Psychology from Pontifical Catholic University of Rio Grande do Sul (PUCRS); Full Professor at Business Administration Graduate Program, School of Administration, Federal University of Rio Grande do Sul (PPGA/EA/UFRGS). E-mail: carmem.grisci@ufrgs.br

Jean-François Chanlat ORCID: https://orcid.org/0000-0003-1878-4707

Ph.D. in Sociology from Montreal University; Professor Emeritus at Dauphine Management Research (DRM), Paris-Dauphine University, PSL. E-mail: francois.chanlat@dauphine.psl.eu 